\title{
The Use of Expert and Documentary Evidence in a Constitutional Attack on a State Criminal Statute: The Marijuana Test Case
}

\author{
Joseph S. Oteri* and \\ Lawrence H. Norris**
}

\begin{abstract}
A
TEST CASE on constitutional grounds of a state criminal statute, notably one governing the use and sale of marijuana, presents many peculiar problems. The subject matter is one of heated and often frantic debate, rising at tinies to the level of public panic. The subject of legislation is a substance about which perhaps more propaganda and misinformation have been spread than about any other drug in our history.

Furthermore, there is considerable pressure from public bodies miltating against candid discussion of the subject by truly qualified experts. The government has, in fact, raised a veritable army of "instant experts" to propound the antimarijuana position-men whose sole claim to expertise is their appointment to official office.

Fimally, despite a liberalizing tendency in recent years, courts remain ill-equipped to accept, digest, and act on material and testimony in areas of bitter controversy, particularly where self-anointed experts are indistinguishable from truly experienced men of science. In fact, one reason for the difficulty is that such testimony is admittedly more appropriate for legislative committee than for a judicial forum. Nonetheless, where the legislature finds itself incapable of acting, as in the reapportionment cases, or where the legislature has already acted on inadequate findings, or where the legislature has acted on findings which evidence to the contrary has since superseded, the courts must take responsibility for seeing that justice is done.

These problems of judicial factfinding all developed in Massachusetts during a recent effort to engineer a test case that finally culminated in a three-week pretrial hearing on the constitutionality of the Massachusetts Narcotic Drugs Law in the case of Commonwealth v. Ivan Weiss and Joseph Leis. ${ }^{1}$
\end{abstract}

* LL.B., Boston College; Member of the Massachusetts Bar.

** IL.B., Suffolk Law School; Member of the Massachusetts Bar. The authors would like to thank Harvey A. Silverglate for his contribution in helping write this article.

${ }^{1}$ No. 28865 (Suffolk Mass. Superior Crim. Court, Dec. 20, 1967). 


\section{I \\ THE LEGAL ISSUES}

The defense in Commonwealth v. Weiss based its constitutional argument on three propositions: first, that a state criminal statute such as the Narcotic Drugs Law violates substantive due process under the fifth and fourteenth amendments unless it has some basis in fact, or bears a rational relationship to the prevention of some harm to either society or individuals such that the state may invoke its police power; second, that a state denies equal protection of the laws under the fourteenth aniendment by allowing one group of people to use a strong intoxicant like alcolol, while prohibiting another group from using an equally harmless intoxicant like marijuana; and finally, that a state violates eiglth anendment strictures against cruel and unusual pumishment by punishing an offense more severely than is justified by the state's interest in preventing the resulting harm.

Assuming the validity of propositions above, the defense then launched a four-pronged assault to convince the court of its responsibility to prevent the state from acting in an unconstitutional manner. It argued first that courts liave the power to hear evidence on the medical, psychological, sociological, and pharmacological aspects of marijuana of the kind more traditionally heard by legislative bodies. Second, the defense argued that courts, on the basis of evidence presented, should judge the dangers of marijuana to determine as a matter of law, subject to appellate review, whether a statute is rationally related to a legitimate legislative aim, and whether it demies equal protection of the laws. Third, the defense argued that courts should evaluate such evidence to determine not only whether a statute is rational, but also whether, in light of the state's interest in regulating marijuana, the penalties are excessive within the meaning of the eighth aniendment. Fourth, the defense urged courts also to evaluate such evidence to determine whether less restrictive alternative means of regulation could be substituted for present legislation without siguifcantly increasing the dangers posed by marijuana.

\section{II}

\section{THE NATURE OF FAC'TFINDING}

To constitute a true test case, a legal attack must be at least capable of invalidating a statute or its application in a significant number of future instances. It must have application beyond the particular parties concerned. As a test case, therefore, it would have been unacceptable for the trial judge in Weiss to find marijuana to be relatively harmless, to declare the statute unconstitutional as applied, and to dismiss the action, if 
another trial judge in a subsequent case could reach an opposite conclusion on the basis of different expert and documentary evidence. Such a result would disrupt the evenhanded administration of justice, and would subject each individual defendant to the lottery of a new factinding process. Furthermore, it would require each new defendant to undertake the expense and effort of gathering expert evidence for his own case.

Clearly, then, to facilitate the orderly and equal administration of justice, courts must be able to resolve questions of marijuana danger with finahty, rather than on an ad hoc basis. The matter must, ultimately, be decided by a court of last resort in such a manner as to apply to all subsequent cases involving the same statute. The defense in Weiss, therefore, asked the court-whatever its final decision-to build a record sufficiently thorough and make findings sufficiently specific to enable the reviewing court to base its ultimate legal decision on adequate information.

In some cases, a constitutional attack purports to show that a statutory classification is invahid merely as apphed to the defendants. ${ }^{2}$ In such a case, a finding of unconstitutionality may turn on the activities or characteristics of the challenging party and of the statute's effect on him. Such facts are adjudicative in nature, and cannot sustain findings for future cases. As such they are made by a trier of fact-judge or jury-to be reviewed, as in the ordinary case, only to discover whether they are supported by the evidence presented. ${ }^{3}$

But where, as in Weiss, extrinsic factual matter is offered for the purpose of showing the factual basis-or the want of one-for a statutory classification, and where the facts are beyond the spheres of judicial notice in the traditional sense, the matter is properly the subject of a "judicial inquiry." And because the inquiry is judicial in character it must be conducted by a judge, and not by a jury. ${ }^{5}$ Furthermore, the facts as determined at the trial are therefore subject to a stricter standard of appellate review. For example, in such a case the appellate court may draw its own conclusions as to a state of facts from information obtained at the trial, ${ }^{8}$ or from additional information received for the first time on appeal. ${ }^{7}$

\footnotetext{
2 Fiske v. Kansas, 274 U.S. 380 (1927).

3 Feiner v. New York, 340 U.S. 315, 316 (1951); Taylor v. Mississippi, 319 U.S. 583, 585-86 (1943).

4 United States v. Carolene Products Co., 304 U.S. 144 (1938).

59 WigMrore, Evidence $\$ 2555$ (d) (3d ed. 1940). See Laurel Hill Cemetery v. San Francisco, 216 U.S. 358, 364-65 (1910).

${ }^{6}$ See Chastleton Corp. v. Sinclair, 264 U.S. 543, 549 (1924).

7 Muller v. Oregon, 208 U.S. 412, 420-21 (1908). See Brown v. Board of Education, 386 U.S. 483, 494 n.11 (1954); Perez v. Sharpe, 32 Cal. 2d 711, 198 P.2d 17 (1948); Conmonwealth v. D'Avella, 339 Mass. 642, 162 N.E.2d 19 (1959).
} 
The reasons for unusual procedure in test cases are obvious; the court decides a question of general application, the ultimate determination of which will be stare decisis, ${ }^{8}$ at least until future experience demonstrates that the basis for the decision no longer exists. ${ }^{0}$ In In re Jenison, ${ }^{10}$ for example, the court held that persons whose religious convictions prohibit compulsory jury duty must be exempt "until and unless further experience indicates ... a serious threat to the effective functioming of our jury system...."

The sine qua non of this test case process is an expansion of the means by which the court receives relevant imformation. R.D. Tway Coal Co. v. Glenn ${ }^{12}$ held, contrary to the decisions heretofore cited, that legislative findings cannot be impeached for the supposed reason that, depending upon the testimony, the same statute might be found constitutional in one case and unconstitutional in another.$^{13}$ Of course, it would be irrational to permit such an issue to be varyingly decided, case by case, on the basis of what various triers of fact might reasonably conclude from varying testimony adnnitted under the rules of evidence applicable in ordinary ad hoc hitigation. Considerations of equality in the treatment of hitigants demand, at least, that the question of a statute's "inherent constitutionality"14 not be decided one way in one case and another way in another. But on the other hand, it would be no more to permit the lottery of such traditional fact finding in one case to become stare decisis for another case. ${ }^{15}$ The only way to avoid either such result is readily apparent. The court must be informed of all relevant data, by whatever appropriate means may be at hand.

In Chastleton Corporation v. Sinclair ${ }_{1}^{10}$ in deciding whether a statute

\footnotetext{
8 See Commonwealth v. Chamberlain, 343 Mass, 49, 175 N.E.2d 470 (1961).

O See, e.g., Chastleton Corp. v. Sinclair, 264 U.S. 543 (1924), where the Court had previously held the law in question to be constitutional.

10267 Minn. 136, 125 N.W.2d 588 (1963).

11 Id. at 137,125 N.W.2d at 589. See Karst, Legislative Facts in Constitulional Litigation, 1960 SuP. Cr. Rev. 75; Burnet v. Coronado Oil \& Gas Co., 285 U.S. 393, 406-08 (1932) (Brandeis, J., dissenting).

1212 F. Supp. 582 (D. Ky. 1935).

13 See Note, 49 Harv. L. REv. 631, 634 (1936).

14 Bickle, Judicial Determination of Questions of Fact Affecting the Constitutional Validity of Legislative Action, 38 HaRv. L. REv. 6, 11 (1925).

15 Consider the following: In Commonwealth v. Wright, 137 Mass. 250 (1884), a jury was "warranted in finding" a certain definitely described and popularly known game to be a lottery. The game came before the court again in Commonwealth v. Sullivan, 146 Mass. 142, 15 N.E. 491 (1888), where it was said that "[t]his having been determined to be a lottery in Commonwealth v. Wright, it is not necessary to go on forever, taking the opinion of the jury in each new case that comes up." Id. at 145,15 N.E. at 494.
}

16264 U.S. 543 (1924). 
had become unconstitutional because the facts upon which legislation was postulated had ceased to exist, Mr. Justice Holmes, speaking for the Court, stated:

These cases show that the Court may ascertain as it sees fit any fact that is merely a ground for laying down a rule of law .... Obviously the facts should be accurately ascertained and carefully weighed, and this can be done more conveniently in the Supreme Court of the District than here. The evidence should be preserved so that if necessary it can be considered by this Court.17

In Brown v. Board of Education ${ }^{18}$ the Supreme Court reled upon a lower court "finding" that segregation leads to the development of a sense of inferiority among Negro children, thereby affecting their motivation to learn. ${ }^{19}$ And, stating that "this finding is amply supported by modern authority," the Court cited a welter of published social psycliological materials. ${ }^{20}$ The decision in Brown is obviously stare decisis for future cases. Because it could not have been based on the kind of factfinding ordinarily present in ad hoc contests, where only the rights of the immediate contending htigants are at issue, restrictions imposed by technical rules of evidence were inappropriate. They are similarly inappropriate in a case involving the marijuana statute.

\section{III}

THE PRESENTATION OF EVTDENCE

The prosecution argued initially, of course, that it was not necessary for the court to hear evidence on the "marijuana question," because the statute was justified as long as a rational relation existed between the statute and a permissible state pohicy. ${ }^{21}$ The defense, on the other hand, argued that because marijuana use and the methods adopted to prevent such use infringe some fundamental rights, the test of statutory validity was whether or not the state possessed a compelling interest in controlling or prohibiting marijuana use. ${ }^{22}$

Yet regardless of the standard used to judge the statute, evidence must be presented. As Mr. Justice Brandeis wrote in O'Gorman \& Young, Inc. v. Hartford Fire Insurance Co.," "[if the] evils did not exist ... for which this statutory provision was an appropriate remedy,"

17 Id. at $548-49$.

18347 U.S. 483 (1954).

19 Id. at 494.

20 Id. at 494 n.I1.

21 Lindsley v. Natural Carbonic Gas Co., 220 U.S. 61 (1911).

22 Sherbert v. Verner, 374 U.S. 398 (1963); Cantwell v. Connecticut, 310 U.S. 296 (1940); Reynolds v. United States, 98 U.S. 145 (1878).

23282 U.S. $251,257-58$ (1931). 
this circumstance, if supported by "some factual foundation of record for overthrowing the statute," would enable a court to overturn the statute on the basis of the evidence presented. The trial judge in Weiss apparently agreed, for he announced that he would give both parties time to gather appropriate evidence.

As an initial decision, for considerations of time, expense, and convenience, the defense decided against the gathering of affidavits and articles and books on the subject, written by experts. For as the research progressed, it became increasingly apparent that the field of marijuana research is plagued with an inordinate number of inaccurate, sensationalistic, and yet often outwardly respectable studies on the dangers of marijuana, many of them perpetuating propaganda released by the Federal Bureau of Narcotics in the 1930's. Given the somewhat shaky foundations of so much antimarijuana hiterature, and hoping to expose the lack of true expertise on the part of the self-proclaimed and governmentanointed "experts" in the drug field, the defense decided to rely entirely on evidence it could subject to cross-examination, and to insist that the prosecution do the same. Despite occasional attempts by the prosecution to introduce into the record objectionable articles and books "for limited purposes only," the trial judge for the most part consistently excluded such evidence and repeatedly announced that he would not consider it.

The cross-examination tactic succeeded beyond all expectation. The defense was careful to present only those expert witnesses who actually shared first hand experience with and knowledge of drugs, including marijuana. Because each witness testified in only a restricted area, nearly a dozen witnesses were required in order to cover the field. Psychiatrists spoke of their patients; sociologists spoke of their chincal observations. The defense exhaustively examined the health, safety, and welfare aspects of marijuana use and even asked experts on religion to testify as to the lack in our society of religious and moral aversion to the use of euphoriants.

Furthermore, the defense decided to reject the tactic of asking individual users of marijuana to testify that marijuana did not necessarily cause insanity, degeneration of the brain, and other effects often attributed to it. It was felt that presentation of such "anecdotal," as opposed to scientific evidence would allow the prosecution to produce scores of troubled persons willing to blame their miseries on the "killer weed," marijuana. By insisting that evidence be tested by scientific method, and that only bona fide scientific experiments be admitted into evidence, the defense succeeded in eliminating personal opinions and anecdotes.

We recognize that others may find use of personal affadavits very helpful. In a "landmarls" case in San Francisco, involving the indictment 
of Melkon Melkonian for selling marijuana, his attorney established an Ad hoc Committee for Repeal of the Marijuana Laws, through which interested laymen could gather affidavits. As the trial progressed, his attorney was able to collect approximately two thousand personal affidavits by individual marijuana users, attesting to the harmlessness of the drug. ${ }^{24} \mathrm{On}$ the basis of affidavits admitted into evidence, Judge Joseph Karesh indicated that he would have ruled on the constitutionality of the state statute had the case involved possession rather than sale of marijuana. ${ }^{25}$

In the Weiss case, all witnesses were asked to describe their personal experiments in great detail. They were questioned carefully on their methods, and on the processes by which they drew conclusions. The defense always retained at its ready disposal in the courtroom at least one man well versed in scientific method and in the literature on marijuana; for despite months of intensive preparations, counsel could not be expected to develop full and subtle mastery of a field at once so complex and sprawhing. Great care was taken beforehand to gather all published works by those known to sympathize with the state's position, thereby enabling the defense to investigate weakness in these works well in advance of the hearing. The nature of the "Establishment" body of scientific "experts" allowed defense counsel to anticipate the identity of most of the state witnesses, although once the hearing began both sides agreed to exchange names of witnesses yet to appear.

As the testimony progressed, the prosecution relied increasingly on the argument that mucl was still unknown about marijuana, and that there was in any case sufficient evidence that marijuana could be harmful if abused by unstable individuals. Realizing that it was virtually impossible to negate altogether the possibility of potential dangers in marijuana, especially in reference to unstable individuals, the defense relied most heavily on the nation's general experience with marijuana, rather than on the bizarre, exceptional case. In those exceptional cases involving bad results from marijuana use, however, the defense was able to disprove causal connections.

Furthermore, the defense refused to claim that marijuana was completely harmless and incapable of abuse. Rather, by arguing that marijuana was less harmful than many substances commonly used and accepted, such as alcohol and tobacco, it placed increasing emphasis on the equal protection argument, particularly as the difficulty became apparent

24 San Francisco Examiner, Dec. 6, 1967, at 8, col. 1.

25 In a companion case involving the California statute against marijuana possession, Judge Karesh refused to impose the mandatory sentence of two to twenty years for a second offender on the ground that to do so would be "brutal." San Francisco Examiner, Dec. 6,1967 , at 8 , col. 1 . 
of arguing that the legislature could not rationally determine that marijuana had some potential for abuse.

Yet most of the emphasis was placed on showing that the legislature could have accomplished its objectives equally well through less restrictive legislation. Even in those cases involving harmful results from marijuana use, the legislature used "overkill" to attack the dangers of abuse. Thus, the witnesses testified on the availability of alternative means of preventing abuse without having to "burn the hoise to roast the pig."

\section{CONCLUSION}

It was hoped, in effect, that the cumulative testimony of experts for both parties would allow the court at least to conclude that the instant statute was so unduly excessive in all respects as to surpass the bounds of due process of law, and that comparison with alcohol and tobacco would cause the court to find that devotees of marijuana were arbitrarily being denied equal protection of the laws. It was hoped that by the end of the hearing, after weighing the social value of the statute against the cost of its enforcement, in terms of wrecked lives and criminogenesis, the court would conclude that the law was certainly not one of those "wholesome and reasonable orders, laws, statutes, and ordinances, directions and instructions"27 which the legislature may enact. Whatever that outcome, however, the defense had encouraged the trial court to act as a master, thereby insuring preparation of an adequate factual record for appeal.

26 Butler v. Michigan, 353 U.S. 380, 383 (1957).

27 Mass. Const. pt. 2 , ch. $1, \S 1$, art. 4 . 